\title{
Impulsiveness and venturesomeness among juvenile offenders
}

DOI: $10.5604 / 01.3001 .0013 .5808$

Grzegorz Kudlak

The Institute for Social Prevention and Resocialisation

University of Warsaw

grzegorz.kudlak@uw.edu.pl

\begin{abstract}
:
The aim of this study was to determine possible relationships between delinquency and the personality traits of the juvenile offenders. The research covered a level of impulsiveness, venturesomeness and empathy among offenders placed in a juvenile shelter in comparison to a control group with a clean criminal record. Results analysis show that personality of juvenile offenders in surveyed dimensions was substantially different from the personality of adolescents in the control group. In particular, the impulsiveness level of juvenile offenders was significantly higher, and the empathy level was significantly lower than of control group. There was no significant differences found in a venturesomeness level in this comparison. The presented research problem certainly requires further studies, particularly focusing on the significance of impulsiveness and empathy as a personality dimension in the genesis of juvenile delinquency, but also in the context of social rehabilitation.
\end{abstract}

Keywords: Juvenile deliquency, juvenile offenders, impulsiveness, venturesomeness, empathy, crime, Eysenck theory, personality, juvenile shelter. 


\section{INTRODUCTION}

Crime is a social phenomenon related to standards, moral code and laws recognized as binding in a given society. According to a dictionary definition, crime means "criminal activity; the total number of offences committed over certain period of time in a given country or social environment, or committed by a given category of perpetrators (...)" [Szymczak, 1979]. Perpetrator is a person "who committed crime for which he/she bears criminal responsibility before the court (...)" [Szymczak, 1979].

Polish legislator treats offensive behaviour of children and adolescents differently from adult behaviour, hence the term "juvenile" is applied in Polish law. Under Article $1 \S 1.1-3$ and $\S$ 2.1 of the Act of 26 October 1982 on proceedings in juvenile matters (Journal of Laws of 2016, item 1654), juvenile offenders are persons younger than 18 (with respect to preventing and combatting their demoralisation), persons who committed a punishable act aged between 13 and 17, and persons subject to educational and corrective measures ordered by the court but no longer than until they turn 21. In 2015, Polish police reported 833281 crimes and 319 399 suspects. These included 12904 juveniles who were found to commit 28875 punishable acts. The group consisted of $82 \%$ boys (Paprocki, 2016). The data shows the significant extent of the negative phenomenon as well as specific gender composition of perpetrators.

The terms "juvenile offender" or "juvenile deliquency" are legal and criminological terms used across the world. They are, however, ambiguous, which results from different criteria adopted for determining basic characteristic features of these terms, i.e. the age limit for person defined as a "juvenile" and the type of acts and behaviours considered an offence. There is a good deal of variety between countries as to the minimum and maximum age limit or the catalogue of acts considered punishable in that period of life (Hołyst, 2005).

Juvenile offending is often confused with adult crime. Equally often, the conduct of youngsters is perceived in general terms, in result of which many behaviours conflicting with applicable legal and moral norms are wrongly perceived as criminal acts. Under Polish law an act committed by a juvenile is not considered a criminal offence, but the term "crime" reflects more fully the scope of the phenomenon. It applies to both punishable acts committed by juveniles, as described in Penal Code and Fiscal Penal Code, as well as certain offences and the problem of demoralisation (Papież, Płukis 2000; Paprocki 2016). 
Demoralisation covers a number of acts where an individual does not respect generally accepted moral values, most frequently by demonstrating criminal behaviour. Polish legislation describes demoralisation as "...violation of the principles of social coexistence, committing a punishable act, systematic evasion from compulsory schooling or vocational training, using alcohol or other substances in order to become intoxicated, prostitution, vagrancy, being member of criminal groups...” (Article $4 \S 1$, Act of 26 October 1982 on proceedings in juvenile matters - Journal of Laws of 1982, No. 35, item 228). Behaviour of a juvenile who is younger than 13 but committed a punishable act, and of a juvenile between 13 and 17 who committed a misdemeanor not constituting a punishable act or a fiscal misdemeanor, may be considered by a family court judge to be a manifestation of demoralisation within the meaning of regulations on proceedings in juvenile matters (Sochacki, 2008). To make things easier, this paper uses the term "juvenile offenders" to describe adolescents manifesting demoralisation and committing punishable acts.

Currently binding Polish law governing the procedures relating to at-risk youth and juveniles committing punishable acts (juvenile offenders) is the Act of 26 October 1982 on proceedings in juvenile matters (consolidated text Journal of Laws of 2014, No. 0, item 382). Preamble thereto presents two aims of the legal act:

1. Prophylaxis understood as prevention of demoralisation and crime among the juveniles,

2. Social rehabilitation understood as creating conditions for return to normal life for the juveniles who committed crime or violated norms of social coexistence, as well as fostering educational, caring and responsibility roles of the juvenile's family.

Juvenile offenders are subject to custodial measures in the form of placement in a detention centre or juvenile shelter (Różańska-Kozieł, 2016). The main aim and task of these institutions is to socially rehabilitate the juveniles assuming the change of their attitude toward socially acceptable behaviour, thus allowing for proper personality development, shaping positive interests and motivations, building proper system of values and respecting the set norms of social coexistence. These tasks are performed through the following educational measures: teaching, coaching, vocational training, organising free-time activities (Różańska-Kozieł, 2016). 
In addition to the above mentioned, detention centres implement the following specific goals that directly relate to the personality domain of the juveniles (Różańska-Kozieł, 2016):

- Eliminating factors that cause personality disorders;

- Developing proper personality structure by removing negative changes caused by the above mentioned factors;

- Strengthening the achieved results of social rehabilitation, providing inspiration for self-education.

It is worth noting that juvenile shelters offer its charges only initial social rehabilitation, particularly with respect to personality and cognitive diagnosis. The courts, based on the results of tests and the degree of demoralisation, make the decision regarding subsequent fate of the charges (Różańska-Kozieł, 2016).

In the light of the significance and the presented extent of juvenile delinquency, it is important to analyse the possible association between selected personality factors and demoralisation of adolescents. This paper and the author's own research aim to establish if there is a significant correlation between impulsiveness, venturesomeness and empathy, and criminal behaviour among the juveniles. Conducting this type of research among adolescents may help to clarify if "problem" adolescents and juvenile offenders truly stand out in terms of personality traits as compared to their age group, or if the cause of their problems should be attributed to external factors only. In the context of social rehabilitation issues, addressing the possible connection between personality traits and juvenile delinquency could constitute an important development, allowing to adjust presently applied preventive measures and to design proper educational and rehabilitative procedures.

\section{FACTORS RELATED TO JUVENILE DELINQUENCY}

The factors that affect juvenile delinquency include intrapsychic and environmental factors. The latter's most important elements include family, significant others and the closest peer group. The first and most frequently listed factor that predisposes to majority of criminal behaviours among adolescents is a dysfunction in the perpetrator's family, whereas a family properly fulfilling its role is reported to play a protective role. Family is the first source for the child's contact with the outside world and provides the child with his/her first experiences. In 
the course of socialisation, the child learns social norms, meets with approval or negation of different types of behaviour, and shapes his/her attitudes (Katarzyna BadźmirowskaMasłowska, 2000). Whether parents provide the child with a sense of security, understanding and unconditional love strongly influences his/her development, both emotional and intellectual. The first years of life and the condition of the family, understood as mutual relations and ties between its members, shape the child's personality and his/her resources. Parental approval, respect and promotion of child's development forms the child's pro-social attitude (Pospiszyl, 2011).

Other pathologic factors that may be present among families and promote juvenile delinquency include: alcohol abuse by parent(s), single parenthood, limited material resources, poor education, family violence (Badźmirowska-Masłowska, 2000). According to studies by Rothbaum and Weisz (1994) negative impact of family's dysfunction accumulates as the child gets older. Moreover, according to Crockenberg and Litman (1990), boys show higher susceptibility to negative influence of parents (particularly mothers). In this respect, there seems to be certain analogy to the percentage of boys in the juvenile offender group, as discussed above.

A key intrapsychic factor that affects criminal behaviour, in addition to physiologic ones, is personality. Scientists have long been looking for personality traits that, in a specific concentration, could indicate individual criminal tendencies. The research, however, is ambiguous, both in terms of defining the studied trait and the results. Modern studies on juvenile delinquency are based on different dynamic models that take into account many factors affecting one another (Siemionow, Jurek, 2016). This trend was supported by the development of personality theory, which allowed to conduct many studies aiming to determine the elements of personality structure that may be responsible for criminal behaviour. The scientists usually focus on personality structures such as: needs, attitudes, value system, self-image, internal image of the world, self-esteem, self-acceptance, sense of purpose, identity (Hołyst, 1993).

For example, N. Han-Ilgiewicz, based on long-term observation of juvenile offenders, recognizes their characteristic traits, such as: inadequate acceptance of norms, inability to accommodate as the cause for failure to adjust, inability to identify with pursued goals and 
values, inconsistency or even conflict with self-sense, or failure to understand oneself (as cited in: Szałański, 1998).

H. Namowicz, among the correlators of juvenile delinquency, lists: susceptibility to suggestions, low ability to form emotional ties, uncontrolled impulsiveness and aggressive reactions. Pospiszyl pointed to hampering effect of fear on criminal behaviour (as cited in: Szałański, 1998).

J. Konopnicki recognizes frustration resulting from school failures as the key psychological mechanisms in behavioural dysfunctions. This theory assumes that dysfunctional behaviour is a manifestation of rebellion against authority, whereas emotional instability, aggression and theft is a defensive reaction (as cited in: Szałański, 1998).

Previous studies have also often referred to factors such as the level of neuroticism, extraversion-introversion, or psychoticism. For these traits, the personality theory of Eysenck is prevalent, according to which criminal tendencies may be manifested in everybody, but in majority of cases they are inhibited by conscience, social or moral norms. Some persons who commit crimes have problem, in the author's opinion, to internalise moral standards due to faulty environmental conditions. Eysenck also pointed out that tendency for antisocial behaviour may characterise persons who are particularly extroversive and neurotic, and thus impulsive (as cited in: Szałański, 1998).

Possible association of impulsiveness with juvenile delinquency and addictions has also been noted by Stautz and Cooper (2013). Even though studies on impulsiveness have been conducted in the field of psychology for a long time, there is still no clear, generally acceptable definition of the trait and the answer to basic questions concerning its nature are still pursued (Sharma, Markon, Clark, 2014). Impulsiveness is considered a symptom of many psychologic dysfunctions and it is listed as one of diagnostic criteria for many disease entities. However, this trait can also be analysed as a personality element of people that function normally and do not suffer from any mental disorder (Jakubczyk, Wojnar, 2009).

Eysenck's personality theory (1985) defines impulsiveness as a continuous tendency to take risks, act spontaneously, make rapid decisions. Other approaches also mention impulsiveness in the context of premature, overly risky behaviours that are inadequate in a given situation. 
Some researchers characterise impulsiveness as an inability to delay gratification or describe it as a contradiction to being composed and self-controlled (Jakubczyk, Wojnar, 2009).

According to Moeller et al. (2011) impulsiveness should be understood as a multidimensional construct specifying predisposition to rapid, unintended reactions to external and internal stimuli, without paying attention to potential negative consequences of these behaviours. Moeller at al. stress that impulsive acts are taken too quickly to properly assess their consequences. It is, therefore, in some sense unintentional or spontaneous behaviour (Moeller et al. 2011; Jakubczyk, Wojnar, 2009).

Eysenck (1985) stresses the difference between impulsiveness and venturesomeness. An inherent element of risk preferences is the awareness of the actions taken and decisions made. From the perspective of a behavioural observer, the frame of both types of the traits may seem very similar, as both venturesomeness and impulsiveness may translate into inclination to meet challenges or to adopt measures of potentially negative or unknown consequences. In the case of the former trait, the person is, however, aware of the possible outcomes, estimates them and takes them into account. Venturesomeness is, therefore, compared to audacity. In case of impulsiveness, the decisions are made without such analysis, and the risk is not calculated or expected, therefore this trait is compared to carelessness (Jakubczyk, Wojnar 2009). It is not difficult to associate this type of behaviour with hasty, potentially harmful behaviour among adolescents that, as may seem, leads to offences or criminal acts.

Another dimension considered in the context of juvenile delinquency, this time as a protecting factor, is empathy. As in the case of other terms discussed in this paper, also the definition of empathy is ambiguous and presented differently in psychology literature.

D. Goleman (2006) describes empathy in direct reference to emotional intelligence and basic social competences. "It is the capacity to identify with another person and experience his/her feelings (...). The key to feel the emotions of another person is the ability to read nonverbal signals: tone of voice, gesture, facial expression, etc.".

Strelau and Doliński (2008) define empathy as “(...) imaginatively placing oneself in another's world - to think, feel and act as that person". They also draw attention to the fact that empathy requires specific developmental competencies, “(...) true empathy requires 
advanced forms of cognitive development that allow to separate own emotional state from that of another's, as well as to become aware of this difference in specific contexts".

Empathy is understood as an emotional reaction leading to experiencing the emotions of others as one's own, to feel compassion and syntony. Empathy, understood as a cognitive process, is the capacity to place oneself in another's position and, therefore, to discern the feelings, thoughts and needs of others. It is often identified with the ability to enter the cognitive situation and social role of another person (as cited in: Szmukier, 1989).

According to E. Aronson et al. (2012), empathy is "the capacity to put oneself in another's shoes, to sample the feelings of another and to experience from within the frame of reference of that other person". While further discussing the theme of empathy Aronson points out to its role in the so called empathy-altruism hypothesis, according to which "feeling empathy for a person in need evokes motivation to help that person regardless of consequences". Empathy depends on altruistic behaviour, it is related to cooperation, positively influences the process of controlling and hampering of aggression, correlates with the feeling of guilt due to the ability to anticipate situations and accepting the role of a victim. It has been shown that empathy also leads to constructive solution of social conflicts (Aronson et al., 2012). In this context, the correlation between high level of empathy and decreased level of readiness to undertake measures that may cause direct harm, suffering and discomfort of others is recognized as of potential significance.

\section{ORIGINAL RESEARCH}

Taking into account theoretical background and research problem discussed above, new studies were planned aiming to determine the level of impulsiveness, venturesomeness and empathy among offenders placed in a juvenile shelter in comparison to a control group with a clean criminal record in population at large. In view of the assumption that there is a link between the fact of committing punishable acts and the structure of personality of the juvenile perpetrator, a base hypothesis was formed (H0) that the personality of juvenile offenders in surveyed dimensions is substantially different from the personality of adolescents in the control group. With respect to theoretical background presented in the introduction, the following specific hypotheses were made for the specific dimensions: 
- $\mathrm{H} 1$ - juvenile offenders present the level of impulsiveness that is higher than average in the control group;

- $\quad \mathrm{H} 2$ - juvenile offenders present the level of venturesomeness that is higher than average in the control group;

- $\mathrm{H} 3$ - juvenile offenders present the level of empathy that is lower than average in the control group.

Own research was conducted on a group of 37 juvenile offenders, males aged from 15 to 18 , pupils of $1^{\text {st }}$ and $2^{\text {nd }}$ grade of middle school, staying at one of juvenile shelters in Warsaw (study group, further referred to as "SDN"). The control group was composed of boys with a clean criminal record, aged from 15 to 16 , pupils of $1^{\text {st }}$ and $2^{\text {nd }}$ grade of a Warsaw middle school (60 persons, control group, further referred to as "GIM"). Both groups were tested with the paper-pencil method, using IVE Questionnaire (Eysenck's Impulsivity Inventory) of H. J. Eysenck and S. B. G. Eysenck (2006), adapted to Polish by A. Jaworowska (2011). IVE is a self- administered questionnaire. It is composed of 54 items in the form of questions using a yes/no format. The results are presented on three sub-scales: Impulsiveness, Venturesomeness, and Empathy. The tool is used for research purposes and in individual diagnosis for identification of socially deviant persons (clinical psychology), recruitment and employment selection (psychology of work), and vocational consultancy (educational psychology). Polish norm is available.

Raw scores for both groups were compared parametrically using the t-Student test for two independent samples, with the assumed level of statistical significance of $p<=0.05$. For presentation purposes the average was applied as the measure of central tendency. The results were also compared to standards for analogous age group calculated for Polish version of the test, where sten of $1-3$ indicated low score, sten of $4-7$ indicated average scores and sten of $8-10$ indicated high scores. Statistical calculations were made using Statistica 13 software (StatSoft).

\section{RESULTS OF OWN RESEARCH}

The summary results of conducted research in relations to study and control groups are presented in Table 1. Variability of results for both groups was comparable (average deviation of $3.21-3.63$ ), except for venturesomeness in the SDN group, where the scores seem more 
coherent (standard deviation of 2.49). With relations to normative population, all results fall within average intensity of the studied traits (sten scores $4-7$ ). Statistically significant differences were, however, noted at the level of raw scores (Table 1).

Tab. 1. Comparison and statistics of IVE results (t-test)

\begin{tabular}{|l|c|c|c|c|c|c|c|}
\hline \multirow{2}{*}{ IVE Results } & \multicolumn{2}{|c|}{$\begin{array}{c}\text { Juvenile offenders } \\
\text { SDN, } \mathbf{n}=\mathbf{3 7}\end{array}$} & \multicolumn{2}{|c|}{$\begin{array}{c}\text { Control } \\
\text { GIM, } \mathbf{n}=\mathbf{6 0}\end{array}$} & \multirow{2}{*}{ t } & df & p \\
\cline { 2 - 8 } & Average & Std. dev. & Average & Std. dev. & & & \\
\hline $\begin{array}{l}\text { IMPULSIVENES } \\
\text { S }\end{array}$ & 10.27 & 3.63 & 7.53 & 3.50 & -3.687 & 95 & $0.0007^{*}$ \\
\hline $\begin{array}{l}\text { VENTURESOME } \\
\text { NESS }\end{array}$ & 10.43 & 2.49 & 11.12 & 3.18 & 1.115 & 95 & 0.26780 \\
\hline EMPATHY & 10.22 & 3.21 & 12.05 & 3.24 & 2.716 & 95 & $0.00785^{*}$ \\
\hline
\end{tabular}

Analysis shows that there are statistically significant $(p<=0.05)$ differences in 2 out of 3 studied dimensions. Impulsiveness among juvenile offenders in the SDN group is at an average level (sten 6, raw score 10.27) and it is significantly higher $(\mathrm{p}<=0.05)$ that the score of the control group (sten 5, average raw score 7.53). The level of venturesomeness in the SDN group is at an average level (sten 6, average raw score 10.43), whereas, with the assumed significance level, there were no differences noted against the control group (sten 6, average raw score 11.12). The level of empathy in the group of juvenile offenders was medium (sten 5, average raw score 10.22) and it was significantly lower ( $p<=0.05$ ) that the score for control group (sten 7, average raw result 12.05).

In light of the presented results, considering the assumed significance level, a difference was established in 2 out of 3 studied personality dimensions. With considerable confidence it is, therefore, possible to confirm the base hypothesis ( $\mathrm{H} 0)$ that the personality of juvenile offenders is significantly different from adolescents in the control group. For specific hypotheses, there are no grounds to reject hypothesis $\mathrm{H} 1$ - juvenile offenders present the level of impulsiveness that is higher than average in the control group; and $\mathrm{H} 3$ - juvenile offenders present the level of empathy that is lower than average in the control group. The analyses do not, however, provide grounds to confirm hypothesis $\mathrm{H} 2$. With the assumed significance level juvenile offenders present the level of venturesomeness no different than the control group. 


\section{SUMMARY AND CONCLUSIONS}

The results obtained in the course of original research partially correlate with the theoretical background presented above and may indicate the connexion between impulsiveness and juvenile delinquency. It is puzzling, however, why the research did not show any significant differences between offenders and non-offenders with respect to venturesomeness. It is worth to note the different structure of this particular personality trait. According to Eysenck's definition, venturesomeness, in contrast to impulsiveness, places greater reliance on calculated risk and conscious acceptance of any negative consequences. Therefore, the cognitive and intellectual layer plays a more dominant role in this respect (Jakubczyk, Wojnar 2009).

Impulsiveness seems to rely more on emotional dominant and unconscious aspect. Juvenile offenders may, therefore, take actions of potentially negative impact more hastily than their peers in the control group, acting less rationally and deliberately. It may be linked to a number of factors related to the history of life of juvenile offenders, such as inadequate training in the family of origin, emotional problems or supporting rash, ill-judged behaviours in the peer environment (Biskupska, 2004).

The author's research conducted in 2015 showed that the level of social competence among offenders placed in a juvenile shelter is significantly lower as compared to adolescents with a clean criminal record (Kudlak, 2015). These differences were shown both with respect to the general level of social competence and the skills conditioning appropriate functioning in situations of social exposition that require assertiveness. The results seem to correlate directly with lower level of empathy in the study group, as shown in the own research conducted, which is an important part of social competence. In the context of the cited empathy-altruism theory of Aronson et al. (2012) it may be assumed that the lower level of empathy may be related to the juveniles' higher likelihood to violate social norms or commit punishable acts. The obtained results could, potentially, indicate the important role of empathy as a factor protecting against demoralisation - proving this theory, however, requires further in-depth studies.

The pursuit of the cause for low level of empathy in the group of juvenile offenders may rely on the definition of Strelau and Doliński (2008) who point out the correlation between 
empathy, specific intellectual skills and emotional maturity. According to M. Sitarczyk (2004) juvenile offenders react more emotionally to every-day problems and situations. Their resistance to stress is much lower, they give up more easily. It is also more difficult for them to control their emotions, which may translate into their ability to feel empathy.

It is obvious that none of the discussed factors fully guarantees future criminal behaviour of a young person, just as not all families with pathological or dysfunctional traits produce criminals. The reason for greater resilience or more effective coping with difficult situations among some people may be their better developed, stable personality structure and support from a person outside the dysfunctional system. The significance of the obtained results for effective social rehabilitation of offenders in a juvenile shelter should be stressed, particularly in the areas where they may experience some deficits, i.e. relating to responsible, reasonable decision making or the capacity to assume another person's perspective and understand his/her emotional reactions. It seems that these are the competencies that the juveniles are lacking, particularly in the light of the results obtained.

The presented research problem certainly requires further studies, particularly focusing on the significance of impulsiveness as a personality dimension in the genesis of juvenile delinquency, but also in the context of social rehabilitation. The significance of empathy, as a factor protecting against demoralisation, should also be stressed, just as the importance of its conscious development in educational processes implemented in social care centres and institutions, but above all in family.

\section{LITERATURE}

Aronson E., Akert R.M., W. D. Tomothy. Psychologia społeczna. Serce i umysł. Zysk i s-ka: Warszawa, 2012.

Badźmirowska-Masłowska K. Młodociani sprawcy zabójstw w Polsce. Kantor Wydaw. "Zakamycze": Kraków, 2000.

Biskupska A. Przestępczość nieletnich. Przyczyny przestępczego wykolejenia i rodzaje czynów przestępczych. Zamość, 2004, Access 09-09-2017: http://www.wszia.edu.pl/images/old/inne/zeszyty_nr3/61-65.pdf 
Crockenberg, S., C. Litman. "Autonomy as competence in 2-year-olds: Maternal correlates of child defiance, compliance, and self-assertion". Developmental Psychology, 26(6)1990, 961-971.

Goleman D., “The Socially Intelligent Leader”. Educational Leadership. 64(1)2006, 76-81.

Eysenck S. B. G, H. J. Eysenck, P. Barret. “A Revised Version of the Psychoticism Scale”. Person. Individ. Diff. 6(1)1985, 21-29.

Hołyst, B. Psychologia kryminalistyczna. Warsaw: LexisNexis, 2005.

Hołyst B., „Przestępczość nieletnich” in Encyklopedia pedagogiczna, eds. Pomykało W. (Wyd. Innowacje: Warszawa, 1993).

Jakubczyk A., M. Wojnar, „Impulsywność - definicje, teorie, modele”. Postępy Psychiatrii i Neurologii 2009; 18 (4): 349-356.

Jaworowska, A., Kwestionariusze osobowości Eysencka EPQ-R, EPQ-R w wersji skróconej: polskie normalizacje. Pracownia Testów Psychologicznych Polskiego Towarzystwa Psychologicznego: Warszawa, 2011.

Kudlak G., „Kompetencje społeczne nieletnich przestępców” in Instytucjonalna Resocjalizacja Nieletnich. Wyzwania i perspektywy rozwoju. eds G. Kudlak (Warszawa: Difin, 2016) 153-165.

Moeller F. G., Barratt E. S., Dougherty D. M., Schmitz J. M., Swann A. C., "Psychiatric aspects of impulsivity”. Am J Psychiatry. 2001; 158 (11): 1783-93.

Papież J., A. Płukis, eds Przemoc dzieci i młodzieży w perspektywie polskiej transformacji ustrojowej. UMK: Toruń 2000.

Paprocki M., „Zjawisko przestępczości nieletnich w latach 2013-2015”. PROBACJA, 2016/I s. 141-155.

Pospiszyl I. Patologie społeczne. PWN: Warszawa, 2011.

Rothbaum F., Weisz J. R. "Parental caregiving and child externalizing behavior in nonclinical samples: a meta-analysis". Psychol Bull. 1994, 116(1): 55-74.

Różańska-Kozieł I. „Zakłady poprawcze i schroniska dla nieletnich. Ministerstwo Sprawiedliwości." Access 16.09.2017: https://ms.gov.pl/pl/dzialalnosc/zaklady-poprawczeschroniska-dla-nieletnich/

Sharma L., K. E., Markon, L. A. Clark, "Toward a theory of distinct types of "impulsive" behaviors: A meta-analysis of self-report and behavioral measures." Psychological Bulletin 2014, Vol 140(2), 374-408. 
Siemionow J., Jurek P., „Psychometrycznie opracowanie skali przekonań utrudniających adaptację społeczną młodzieży” Polskie Forum Psychologiczne, 2016, 21(1), s 123-144.

Sitarczyk, M. Nieletni sprawcy zabójstw. Sylwetki psychologiczne. UMCS: Lublin, 2004.

Sochacki, A. Postępowanie w sprawach nieletnich. Materiał dydaktyczny. Wydawnictwo Szkoły Policji w Słupsku: Słupsk, 2008.

Stautz K., A. Cooper, "Impulsivity-related personality traits and adolescent alcohol use: a meta-analytic review”. Clin Psychol Rev. 2013 Jun;33(4): 574-92

Strelau J., D. Doliński. Psychologia - podręcznik akademicki. PWN: Warszawa, 2008.

Szałański J., „Mechanizmy psychologiczne wykolejenia przestępczego i resocjalizacji w świetle wyników dotychczasowych badań krajowych”, in Wina - kara - nadzieja przemiana. eds J. Szałański. (Łódź - Warszawa - Kalisz, 1998).

Szmukier, T., „Z rozważań nad regulacyjną rolą empatii”, Przegląd Psychologiczny 1989, no. 4, p. 861-876.

Szymczak M. eds. Słownik języka polskiego, Ed II. PWN: Warsaw, 1979. 